\begin{tabular}{|l|l|l|}
\hline \multicolumn{2}{|c|}{ PublisherInfo } \\
\hline \hline PublisherName & $:$ & BioMed Central \\
\hline \hline PublisherLocation & $:$ & London \\
\hline \hline PublisherImprintName & $:$ & BioMed Central \\
\hline \hline
\end{tabular}

\title{
Architectural role for BCL6
}

\begin{tabular}{|l|l|l||}
\hline \multicolumn{2}{|c|}{ ArticleInfo } \\
\hline \hline ArticleID & $:$ & 3820 \\
\hline \hline ArticleDOI & $:$ & $10.1186 /$ gb-spotlight-20001107-02 \\
\hline \hline ArticleCitationID & $:$ & spotlight-20001107-02 \\
\hline \hline ArticleSequenceNumber & $:$ & 257 \\
\hline \hline ArticleCategory & $:$ & Research news \\
\hline \hline ArticleFirstPage & $:$ & 1 \\
\hline \hline ArticleLastPage & $:$ & 2 \\
\hline \hline & & RegistrationDate : 2000-11-07 \\
ArticleHistory & $:$ & OnlineDate $\quad$ 2000-11-07 \\
\hline \hline ArticleCopyright & $:$ & BioMed Central Ltd2000 \\
\hline \hline ArticleGrants & $:$ & \\
\hline \hline ArticleContext & $:$ & 130591111 \\
\hline \hline
\end{tabular}




\section{Jonathan B Weitzman}

Email: jonathanweitzman@hotmail.com

Nuclear BTB/POZ proteins are often concentrated into discrete nuclear subdomains, but the role of these nuclear compartments is unclear. The BCL6 proto-oncogene, frequently altered in non-Hodgkin lymphoma, encodes a POZ/zinc finger protein that shows a characteristic localization in nuclear aggregates. In the November Molecular and Cellular Biology Albagli et al. used a tetracyclineregulated, epitope-tagged BCL6 allele to explore the significance of BCL6 aggregates ( $\mathrm{Mol} \mathrm{Cell} \mathrm{Biol}$ 2000, 20:8560-8570). They employed pulse-labeling with bromodeoxyuridine (BrdU) together with electron- and laser-scanning confocal microscopy to determine the relationship between BCL6 expression and DNA replication. Electron microscopy showed that BCL6 is associated with early, mid and late replication foci during $\mathrm{S}$ phase. Careful ultrastructural analysis revealed that newly synthesised DNA appears wrapped around the BCL aggregates. Albagli et al. propose that BCL6 recruits chromatinregulating proteins to nuclear subdomains, providing an organisation structure for the replication apparatus.

\section{References}

1. The POZ domain: a conserved protein-protein interaction motif.

2. Alterations of a zinc finger-encoding gene, BCL-6, in diffuse large-cell lymphoma.

3. Molecular and Cellular Biology, [http://intl-mcb.asm.org]

This PDF file was created after publication. 